\title{
The Impact of Intrinsic Motivation on Employee's Job Satisfaction
}

\author{
M.Yousaf Raza ${ }^{1, *}$, M Waheed Akhtar ${ }^{2}$, Mudassir Husnain ${ }^{3}$ \& M Saeed Akhtar ${ }^{4}$ \\ ${ }^{1}$ Department of Management Sciences, Mohi ud din Islamic University, Islamabad, Pakistan \\ ${ }^{2}$ Faculty of Management Sciences, International Islamic University, Islamabad, Pakistan \\ ${ }^{3}$ International Islamic University, Islamabad, Pakistan \\ ${ }^{4}$ Punjab Vocational Training Council, Pakistan \\ *Correspondence: Department of Management Sciences, Mohi ud din Islamic University, Islamabad, Pakistan. \\ E-mail: Yousaf.raza@miu.edu.pk
}

\author{
Received: April 23, $2015 \quad$ Accepted: May 7, $2015 \quad$ Online Published: July 18, 2015 \\ doi:10.5430/mos.v2n3p80 URL: http://dx.doi.org/10.5430/mos.v2n3p80
}

\begin{abstract}
The main purpose of present study is to identify the impact of intrinsic motivation on employee's job satisfaction. This is basically an empirical study and a scale was developed to find out the impact of four variables namely; job security, achievement, job responsibility and work itself (intrinsic motivation). The questionnaire was distributed among the respondents on the basis of simple random sampling. The findings of this study show a significant positive relationship among four variables and employees job satisfaction. The relationships among job security \& job satisfaction, achievement \& job satisfaction, job responsibility \& job satisfaction and work itself and job satisfaction are significant and positive. This research study highlights the areas in which the organizational manager focuses to increase the individual and organizational performance.
\end{abstract}

Keywords: Job security, Achievement, Job responsibility, Work itself, Country of origin, Employees satisfaction, Pakistan

\section{Objective of the Study:}

The main objective of this research is to investigate the impact of intrinsic motivational factors on job satisfaction. Because in Pakistan the study related to intrinsic motivation is not conducted so we are going to investigate this issue.

Research methodology: Data was collected from the different organizations and employees working in different organizations of Pakistan. The survey was completed by 182 employees, 95\% responses were observed. The Results were made using Correlation, regression and ANOVA with the available data.

Findings: The results showed that intrinsic motivation and employee's job satisfaction are reducing the risk. Finding is that employees' perception diverges significantly during the organizational problems.

\section{Introduction}

In the last two decades the organization moved globally to capture the international market and when an organization moved globally than it must focud on its employees. that's why organization used the HR policies such as development of competencies, ethics, attractive work and mostly employers are focus on create jobs and conditions that satisfy the employees (nielspors 2002). There are many factors which are effect on job satisfaction. (Dinham and Scott, 1998) stated three factors that effect on job satisfaction intrinsic factors, operating factors and system level factors. Intrinsic motivation is clearly important types of motivation, most of the activities people do are not, strictly speaking, intrinsically motivated. This is especially the case after early childhood, as the freedom to be intrinsically motivated becomes increasingly curtailed by social demands and roles that require individuals to assume responsibility for non essentially interesting tasks. In schools, for example, it appears that intrinsic motivation becomes weaker with each advancing grade(Ryan and Deci 2000). Most consistent finding to emerge from this body of research is that intrinsic motivation is strongly tied to positive performance outcomes(Abuhamdeh, Csikszentmihalyi et al. 2015). 
In 1959 the researcher Frederick Herzberg presents a two factor theory. In this theory he argues that there are some factors which lead to satisfaction and other are that inhibit dissatisfaction. He argued that motivational factors (sense of achievement, advancement opportunities, moral values, job security) lead to employee satisfaction (herzberg, 1959).

This research is follow the studies (Hancer and George, 2003; smith et al., 1996;simons and Enz, 1995) that use distinct intrinsic factors categories to explore job satisfaction. Job satisfaction is a function of the difference between the amount of some outcome provided by a work role and the strength of a related desire or motive on the part of the person". "Job satisfaction is the whole matrix of job factors that make a person like his work situation and be willing to head for it without distaste at the beginning of his work day(Srinivasan and Ambedkar 2015).

In Pakistan employers focus on extrinsic motivation (cash compensation, incentives,) so industrial employees feel much dissatisfaction on their jobs that's why they make the decision to turnout from the organization. The objective of present study is to investigate the impact of intrinsic motivation on job satisfaction in Pakistan. What is the impact of intrinsic motivation on job satisfaction? In this study we offer two contributions in a literature. First, we investigate the some confirmation to suggestion that intrinsic motivation may important for employee's performance (Bonner and Sprinkle, 2002). Second, contribution is investigating the impact of intrinsic motivation on employee's job satisfaction (Frey, 1997).

\section{Literature Review}

$20^{\text {th }}$ century is the surroundings of global rivalry and in this era mostly organization are focusing to achieve the competitive advantage over others. Now a day's many researchers giving their attention to representative career because of technical innovation and global trends which created a blustery ecological context (Arthur and Rousseau, 1996; Hall and Moss, 1998; Mirvisand Hall, 1994; Osterman, 1996; Sullivan, 1999). In administration, it's contended that satisfied workers have higher performance(Alfonso Sousa-Pozaa 2000). Today all the assets are replicated except human assets because the specific skills, expertise, experience and knowledge of an individual can't be copied. So it could be a challenge for an organization how to retain the knowledgeable employees.

Job satisfaction as a general attitude towards an individual's job, and the difference between the amount of reward workers receive and the amount they believe they should receive(Adenuga 2015). Job satisfaction is the match between an individual's expectations and the perceived reality of the job as a whole(Wang and Tran 2015). Job satisfaction as "the fulfillment acquired by experiencing various job activities and rewards". It implied that job satisfaction can be understood as an emotional state of human beings that reflects the positive and pleasant feeling of a person when he or she appreciates his or her own job well(Johnson and Sohi 2014). Many tools are used to retain the best employees but job satisfaction is one of the best. Job satisfaction described in many ways and defined contrarily in many researches. Kartzell (1964) said that there is compromise round job satisfaction, which is the verbal expression of an official's appraisal of his/her job. Locke (1976) describe that job satisfaction is positive feelings which is follow on the assessment of one's job or job experience. Robbins and Coulter (1996) defined that job satisfaction is a employee general attitude towards job(Herzberg 1968) Present a dual factor theory of job satisfaction which tells us there are two group of factor that can lead the job satisfaction and job dissatisfaction. Job content-related facets (achievement, responsibility, security, moral values) lead to satisfaction. So job satisfaction is the best forecasting tool of overall welfare.(Argyle, 1989; Judge and Watanabe 1993).

Job security is explained as one's hope about attaining job situation. It involves relate to over failure of attractive job characteristics such as low chance of advancement opportunities, current working conditions, and long-term career opportunities (Greenhalgh and Rosenblatt, 1984 Jacobson, 1991, Greenhalgh and Sutton, 1991;; Borg and Elizur, 1992). There are more than a few causes for the rising literature on this issue. One narrate to the large number of people unwillingly jobless throughout the 19804.3 million people were lastingly transfer between 1985 and 1989 alone (Herz, 1991). The significance of job security has enlarged and highlight in the last ten years employees feedback why they change the organization (e Davy et al., 1991; .g. Brockner, DeWitt, Grover and Reed, 1990;). In these studies, they defined intrinsic job satisfaction lower due to downsizing, mergers, and restructuring as a cause of turnout (e Brockner et al., 1990; .g. Davy et al., 1991,). So job security and its result are effect on employee satisfaction. Job security was positively and significantly related with job satisfaction (Oldham, Julik, Stepina and Brand, Ambrose, 1986, e.g. Arnold and Feld- man, 1982) and organizational obligation (e.g. Greenhalgh, 1985; Arnold and Feldman, 1982), and negatively connected with purpose to quit (e.g. Ashford et al., 1989; Arnold and Feldman, 1982). 


\section{H1: Job security has a positive effect on job satisfaction}

In this environment organizations are need efficient and effective employees and managers so that organization achieves their objectives. Organizations cannot succeed without their personnel efforts and commitment (A Mohamood\& M Hossain, 2006). Than organization considered and used many tools for employee job satisfaction such as: salaries, achievement, job security and workplace flexibility (Koustelios et al., 2003; Navaie-Waliser et al., 2004; Ilies and Judg, 2003; Gigantesco et al., 2003; McNeese-Smith, 1999; Blegen, 1993; De Loach, 2003; Chu et al., 2003; Thyer, 2003). Number of the researches pointed that the teacher self efficacy having a impact on student achievement and success (Moore \&Esselman, 1992, 1994; Muijs\&Rejnolds, 2001; Ross, 1992, 1998).The opportunities for individual and specialized development and achievement is one of the most excellent predictors of job satisfaction (Lyons et al., 2003; Al-Ahmadi, 2002; Freeborn and Hooker, 1995; Wittig et al., 2003).

\section{H2: Employees achievement has a positive effect on job satisfaction}

Responsibility generally refers to a personal's participation with various job-related events and their results because the consequences have implications for their uniqueness (Britt, 1999). The Triangle Model, which was developed by Schlenker, Britt, Pennington, Murphy, and Doherty (1994), and shows the responsibility is usually having a triadic relationships between events, the rules that regulate these events, and the self images persons have in definite situations. According to Britt (1999, p. 696) the "amount of responsibility an individual feels on any given occasion is a direct function of the strength of the links between the elements and the importance of the elements to the individual. (Schlenker et al. 1994) empirically assessed the Triangle Model and concluded that responsibility was indeed higher when all three relationships in the model were strong. Using the principles prescribed by the model, the discrimination and stereotypes (the events), the pay inequity and biased policies (the rules and regulations), and the low self-concept and performance expectations (the identity images) could all synergistically lower women's perceptions of their own job responsibility.

\section{H3: Job responsibility has a positive effect on job satisfaction}

Many managers in the organization admit that work situation is a cause of employee attitude in the organization and this the area in which HR is manipulates the organization programs and practices of management. The most critical part of the job situation is the work itself which is normally unnoticed by the researcher when they investigate the job satisfaction. Some researcher belief that the work situation itself is most weighted in job satisfaction that is called "intrinsic job characteristics." Studies shows that when they asked to employees to evaluate the job features than the mostly weighted the job itself as a high (Judge \& Church, 2000; Jurgensen, 1978).

Some managers belief that the pay is important for employees as compare to job attributes (interesting work). But (Kovach, K. A. (1995) state that employees ranked the job attributes as the highest and ranked pays as fifth number. All the major job satisfaction facets the work itself is (challenging work, variety \& scope) is the most excellent predictor of overall job satisfaction (Fried \& Ferris, 1987; Parisi \& Weiner, 1999; Weiner, 2000). All the above arguments leads to the following hypothesis.

\section{H4: Work itself has a positive effect on job satisfaction}

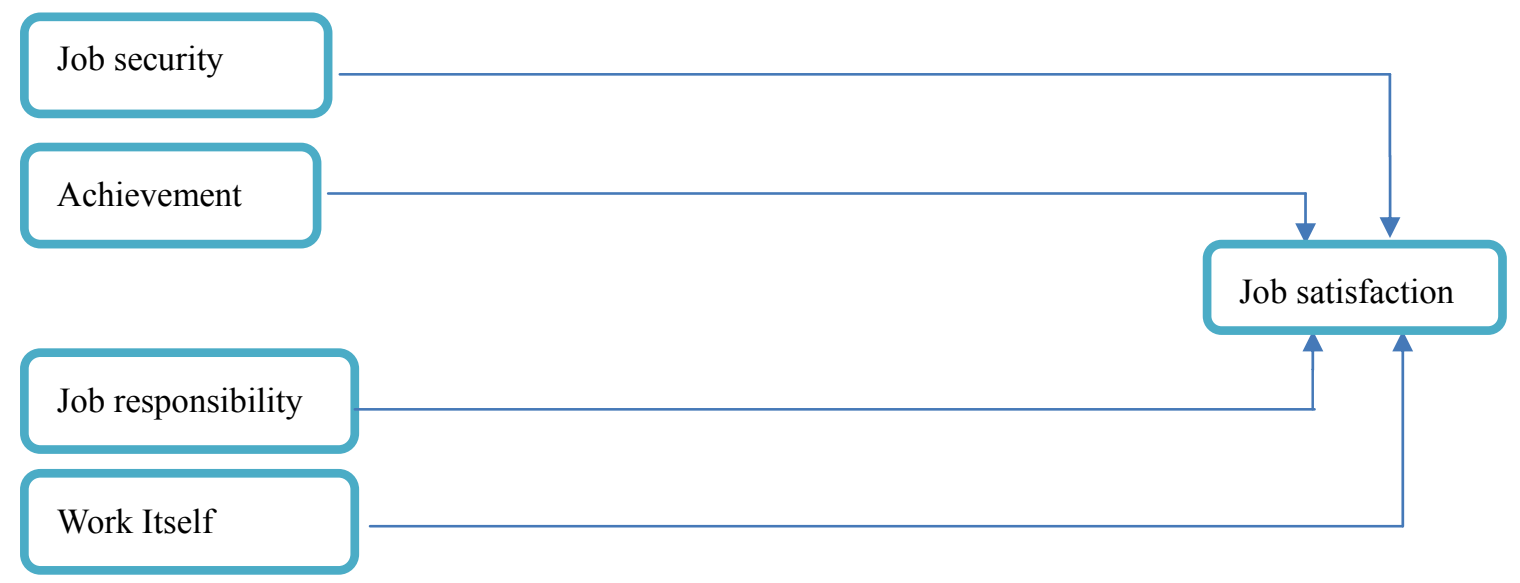

Figure 1. Theoretical Framework 


\section{Methodology}

\subsection{Sample}

The respondents of this study are the employees of the city of Islamabad, which is capital of Pakistan and familiar as intense and culturally dissimilar city (population of Islamabad are having a different background because they belong to all over the Pakistan). We just describe a universal picture that how different factors effect on the employees satisfaction on the job. We used the convenience sampling technique for collecting the data. The survey questionnaire was filled by respondent for the period of November to December 2012. About 205 questionnaires were floated among respondents, out of which 190 were received and 182 were usable. So the response rate was $88 \%$.

\subsection{Variable Measurement}

Dependent variable is job satisfaction and independents variables are job security, achievement, work itself and job responsibility and all these items are measured by using the scale of (Patricia Huddleston and Linda K. Good 1999) in which they used eleven questions to measure these variables by using the lickert scale $(1=$ strongly disagree and 5 = strongly agree) scales have good reliability and these scales are best to get the information about people. The sample of the questionnaire is (Upto what extent you have to receive a chances do something that create your value in organization). The reliability of job satisfaction (.770) job security (.739) achievement (.987) job responsibility (.899) work itself (.903)

\subsection{Demographic}

Table 1 describe Demographic data of respondents, most of respondents were male 75 percent and 25 percent female. Most of the respondents are below 40 years (93\%) of age, 55 percent between the respondents are unmarried

Table 1. Demographic Characteristics

\begin{tabular}{ll}
\hline Age & Percent \\
\hline $18-25$ & 37 \\
$26-35$ & 54 \\
$36-45$ & 09 \\
46 and above & 0 \\
\hline Gender & \\
\hline Male & 75 \\
Female & 25 \\
\hline Marital status & \\
\hline Married & 45 \\
Unmarried & 55 \\
\hline
\end{tabular}

\section{Analysis and Results Descriptions}

In Table two we calculate the mean, standard deviation and correlation of all variables which are used in hypothesis test. And we show the standard deviation, mean, reliability and correlation of each variable in Table 2. To test the reliability of variables we used the cronbach alpha technique. The values of cronbach alpha for all the variables (job satisfaction $0.770>0.70)$, security $(0.739>0.70)$, achievement $(0.897>0.70)$, responsibility $(0.899>0.70)$ and work itself $(0.903<0.70)$ we was studied significant at 0.70 level and this level was recommended by (Nunnally, 1978) and this level was also recommended by (Ndubisi, 2006).

Table 2. Mean Standard deviation, Alpha reliability and Correlation.

\begin{tabular}{llllllll}
\hline & Mean & SD & JS & Res & Ach & Sec & Wr \\
\hline JS & 3.04 & 0.955 & $(0.770)$ & & & & \\
Sec & 3.22 & 0.99 & $0.783^{* *}$ & $(0.739)$ & & & \\
Ach & 3.26 & 1.08 & $0.794^{* *}$ & $0.862^{* *}$ & $(0.897)$ & & \\
Res & 3.17 & 1.05 & $0.821^{* *}$ & $0.849^{* *}$ & $0.862^{* *}$ & $(0.899)$ & \\
Wr & 3.43 & 1.13 & $0.784^{* *}$ & $0.856^{* *}$ & $0.819^{* *}$ & $0.767^{* *}$ & $(0.903)$ \\
\hline **. Correlation is significant at the & 0.01 level (2-tailed). & & & \\
N=182, \\
JS=job satisfaction, Sec=Security, & Ach=Achievement, Res=Responsibility, Wr=Work itself, \\
\hline
\end{tabular}


When we analyze the Table 2, than we see the correlation among job satisfaction and responsibility, JS and achievement, and JS and security, JS and work itself are positive correlate at 0.01 level. In my analysis the value of multicolinearity within all the independent variables are less than 0.80 , so there is no multicolinearity exists between the independent variables. We found the support of Goldsmith et al., (1999) study related to the multicolinearity.

Regression analysis

Table 3 describes the regression analysis among dependent variable job satisfaction and independent variables responsibility, achievement, security \& work itself. The relationship between dependent and all independents variables are significant. The regression equation is

Job satisfaction $=\alpha+\beta 1$ (job security) $+\beta 2$ (achievement) $+\beta 3$ (responsibility) $+\beta 4$ (work itself)

Table 3. Regression Analysis

\begin{tabular}{|c|c|c|c|c|c|c|c|}
\hline \multirow[t]{2}{*}{ Model } & & \multicolumn{2}{|c|}{$\begin{array}{l}\text { Unstandardized } \\
\text { Coefficients }\end{array}$} & \multirow{2}{*}{$\begin{array}{l}\text { Standardized } \\
\text { Coefficients } \\
\text { Beta }\end{array}$} & \multirow[t]{2}{*}{$\mathrm{T}$} & \multirow[t]{2}{*}{ Sig. } & \multirow[t]{2}{*}{$\mathrm{R}^{2}$} \\
\hline & & $\mathrm{B}$ & Std. Error & & & & \\
\hline \multirow{5}{*}{$* * *$} & (Constant) & 0.339 & 0.131 & & 2.581 & 0.011 & 0.731 \\
\hline & $\mathrm{Sec}$ & 0.236 & 0.073 & 0.244 & 3.248 & 0.001 & \\
\hline & Ach & 0.208 & 0.072 & 0.237 & 2.903 & 0.004 & \\
\hline & Res & 0.220 & 0.093 & 0.242 & 2.367 & 0.019 & \\
\hline & $\mathrm{Wr}$ & 0.165 & 0.067 & 0.196 & 2.455 & 0.015 & \\
\hline \multicolumn{3}{|c|}{ *** Dependent Variable: job } & satisfaction & & & & \\
\hline
\end{tabular}

The end result of regression table shows that the connection among job Security and JS is positive and significant $(\beta=0.244, \rho<0.05)$. The beta value of job security describe that if one unit increases or decreased in job security then job satisfaction will increased or decreased by 24 percent. The value is significant because it is lower than 0.05 that's why (H1, job security is positively affects job satisfaction) is accepted. This study confirms the finding of (Arnold and Feld- man, 1982; Oldham, Julik, Ambrose, Stepina and Brand, 1986).

Relationship between achievement and JS is significant $(\beta=0.237, \rho<0.05)$ it describe that if one unit increase in achievement then job satisfaction will be increased by 23.7 percent; (H2, achievement positively affects job satisfaction) is accepted. Our findings provide the same results as with previous studies of (Lyons et al., 2003; Al-Ahmadi, 2002; Freeborn and Hooker, 1995; Wittig et al., 2003).

The relationship between responsibility and JS is significant $(\beta=0.242, \rho<0.05)$ it describe that one unit increase in responsibility than job satisfaction will be increased by 24.2 percent. These findings support $(\mathrm{H} 3$, which was proposed that responsibility has positive effect on job satisfaction). This study confirms the findings of Schlenker et al., (1994)

Similarly work itself and JS is significant $(\beta=0.196, \rho<0.05)$ it describe that one unit increase in work itself than job satisfaction will be increased by 19.6 percent. These findings support ( $\mathrm{H} 4$, which was proposed that work itself has positive effect on job satisfaction).This study confirms the findings of (Hochschild, 1979, 1983).

The value of $\mathrm{R}^{2}$ value is $\left(\mathrm{R}^{2}=0.731\right)$ it shows fitness of good of model. And the explanatory power of our model means that 73.1 percent of the model is explained.

\section{Discussion and Conclusion}

The purpose of this study is to investigate the effect of intrinsic motivational factors (job security, achievement, responsibility and work itself) on job satisfaction. The results show that intrinsic motivational factors are significantly related to employee's job satisfaction.

According to the (Lam et al., 2001) work itself plays a key role in employee job satisfaction. Employee creativity enhances the company ability for gaining competitive advantage. This study reflects that in order to use the creativity of the employees the company must provide them challenging, competitive environments, and variety of tasks. It will also enable the employees to enjoy their job and have a sense of pride about it. Employees feel motivated after getting variety of task on same job and they appreciate their freedom.

Employee's places job security at a high level for behavioral and psychological attachment to an organization (Arnold and Feld- man, 1982). Employees are the key asset for any organization to get sustained competitive 
advantage. This study reflects that employees having job security will increase their loyalty, commitment, attachment and less intention to quit. By providing job security to employee organization retains its high intellectual capital within the organization and gets fruitful results by using their skills.

This study indicates more consistent and stronger relationship between job responsibility and job satisfaction which was reported in past studies (Schlenker et al., 1994). This study reflects that higher job responsibility will engage employees in large number of and diverse tasks and encourage their active participation in problem solving. The organizations focusing on continuous learning, more job responsibility, and problem solving activities for employees will led to decrease in setup times and increase employees involvement for process improvements. Which ultimately expand employee abilities, knowledge and skills to increase production of complex products.

Feelings of achievement have large effect on employee job satisfaction (Hochschild, 1979). This study indicates that employees having low feeling of achievements have more intention to quit. Whereas high feelings of achievements will increase employee satisfaction and performance and less likely to quit, organization can do this at a low cost.

\subsection{Limitations and Suggestions for Future Research}

As there is always room for development, this study comprises the views regarding impact of intrinsic motivation of employee job satisfaction by utilizing convenience sampling, analyzing the views from short sample size and conducted in capital city of Pakistan Islamabad. Surveys were distributed and filled mainly from teachers from different universities. Thus a more comprehensive study needs to be examined with more generalizability by increasing sample size.

Studies on intrinsic motivation should be added with diverse tools and approaches which might demonstrates addition to this field. Moreover, other dimensions such as organizational innovational, risk attitude or characteristics of R\&D employees should be incorporated in future studies model to examine their effects. Furthermore, demographic characteristics of employees may be providing new direction for future studies such as gender, employees occupation sector (Govt or private).

\subsection{Implications for Managers}

These results could have implications for the manager's practice of intrinsic motivation strategies. The structure of employee job will have the opportunity to express their need for autonomy, competitiveness and social association to fulfill intrinsic needs. Therefore, employees need to choose to take part and to experience a sense of accomplishment, and have plentiful opportunity to experience with their peers.

This study provides helpful insights for manager to identify the importance of intrinsic motivation for their subordinate's job, as well as increase in intrinsic motivation will be increase the employee performance. The contribution of employee will lead the organization to achieve its strategic objective in a competitive environment.

\section{References}

Abuhamdeh, S., \& M. Csikszentmihalyi, et al. (2015). Enjoying the possibility of defeat: Outcome uncertainty, suspense, and intrinsic motivation. Motivation and Emotion, 39(1), 1-10. http://dx.doi.org/10.1007/s11031-014-9425-2

Adenuga, O. A. (2015). Impact of Occupational Stress on Job Satisfaction and Mental Health of First Bank Employees: Implication for Personnel Psychologists. Science, 1(1), 15-21.

Al-Ahmadi, H.A. (2002). Job satisfaction of nurses in Ministry of Health Hospitals in Riyadh, Saudi Arabia. Saudi Medical Journal, 23, 645-50.

Alfonso Sousa-Pozaa \& Andre's A. Sousa-Pozab, c. (2000). Well-being at work: a cross-national analysis of the levels and determinants of job satisfaction. Journal of Socio-Economics, 517-538.

Argyle, M. (1989). The Psychology of Happiness. Routledge: London.

Arnold, H., \& Feldman, D. (1982). A multivariate analysis of the determinants of job turnover. Journal of Applied Psychology, 67, 350 \pm 360 . http://dx.doi.org/10.1037/0021-9010.67.3.350

Ashford, S., Lee, C., \& Bobko, P. (1989). Content, causes, and consequences of job insecurity: A theory-based measure and substantive test. Academy of Management Journal, 32, 803 \pm 829 . http://dx.doi.org/10.2307/256569

Blegen, M.A. (1993). Nurses' job satisfaction: a meta-analysis of related variables. Nursing Research, 42(1), 36-40. http://dx.doi.org/10.1097/00006199-199301000-00007 
Borchgrevink, C.P., Nelson, R.H., \& Ruf, J.L. (1998). It is a chef's life. Journal of Hospitality \& Tourism Education, 10(2), 13-18. http://dx.doi.org/10.1080/10963758.1998.10685179

Borg, I., \& Elizur, D. (1992). Job insecurity: Correlates, moderators and measurement. International Journal of Manpower, 13(2), 13 \pm 26 . http://dx.doi.org/10.1108/01437729210010210

Brockner, J., DeWitt, R., Grover, S., \& Reed, T. (1990). When it is especially important to explain why: Factors affecting the relationship between managers' explanations of a layo€ and survivors' reactions to the layoff. Journal of Experimental Social Psychology, 26, 389 \pm 407 . http://dx.doi.org/10.1016/0022-1031(90)90065-T

Career as a Chef. (2007). Career as a Chef. Institute for Career Research, Chicago, IL.

Chitiris, L. (1988). Herzberg's proposals and their applicability to the hotel industry. Journal of Hospitality \& Tourism Research, 12(67), 67-79. http://dx.doi.org/10.1177/109634808801200106

Chu, C., Hsu, H.M., Price, J.L., \& Lee, J.Y. (2003). Job satisfaction of hospital nurses: anempirical test of a causal model in Taiwan. International Nursing Review, 50, 176-82. http://dx.doi.org/10.1046/j.1466-7657.2003.00165.x

Davy, J., Kinicki, A., \& Scheck, C. (1991). Developing and testing a model of survivor responses to layoffs. Journal of Vocational Behavior, 38, 302 \pm 317 . http://dx.doi.org/10.1016/0001-8791(91)90032-H

De Loach, R. (2003). Job satisfaction among hospice interdisciplinary team members. American Journal of Hospital Palliative Care, 20(6), 434-40. http://dx.doi.org/10.1177/104990910302000605

Dinham, S., \& Scott, C. (1998). A three domain model of teacher and school executive career satisfaction. Journal of Educational Administration, 36(4), 362-378. http://dx.doi.org/10.1108/09578239810211545

Eleni Griva, Eugenia Panitsidou \& Dora Chostelidou. (2012). Identifying factors of job motivation and satisfaction of foreign language teachers: research project design Procedia. Social and Behavioral Sciences, 46(2012), 543-547. http://dx.doi.org/10.1016/j.sbspro.2012.05.157

Freeborn, D.K., \& Hooker, R.S. (1995). Satisfaction of physician assistants and othernonphysician providers in a managed care setting. Public Health Rep, 110, 714-9.

Fried, Y., \& Ferris, G. R. (1987). The validity of the job characteristics model: A review and meta analysis. Personnel Psychology, 40(2), 287-322. http://dx.doi.org/10.1111/j.1744-6570.1987.tb00605.x

Ghiselli, R.F., Lalopa, J.M., \& Bai, B. (2001). Job satisfaction, life satisfaction and turnover intent among food-service managers. Cornell Hotel \& Restaurant Administration Quarterly, 42(2), 28-37.

Gigantesco, A., Picardi, A., Chiaia, E., Balbi, A., \& Morosini, P. (2003). Job satisfaction amongmental health professionals in Rome, Italy. Community Mental Health Journal, 39(4), 349-55. http://dx.doi.org/10.1023/A:1024076209376

Goldsmith, R.E., Moore, M.A., \& Beaudoin, P. (1999). Fashion innovativeness and self-concept: a replication. Journal of Product \& Brand Management, 8(1), 7-18. http://dx.doi.org/10.1108/10610429910257904

Greenhalgh, L. (1985). Job insecurity and disinvolvement: Field research on the survivors of the layoff. Presented at the National Academy of Management Meetings, San Diego, CA.

Greenhalgh, L., \& Rosenblatt, Z. (1984). Job insecurity: Toward conceptual clarity. Academy of Management Review, $9,438 \pm 448$.

Greenhalgh, L., \& Sutton, R. (1991). Job insecurity and organizational effectiveness. In: Hartley, J.Jacobson, D., Klandermans, B., \& van Vuren, T. (Eds.), Job Insecurity: Coping with Jobs at Risk. Sage, London.

Herz, D. (1991). Worker displacement still common in the late 1980's'. Monthly Labor Review, 114, $3 \pm 9$.

Herzberg, F. (1968). One more time: how do you motivate employees?. Harvard Business Review, 53-62.

Ilies, R., \& Judg, T.A. (2003). On the heritability of job satisfaction: the mediating role of personality. Journal of Applied Psychology, 88(4), 750-9. http://dx.doi.org/10.1037/0021-9010.88.4.750

Jacobson, D. (1991). Toward a theoretical distinction between the stress components of the job insecurityand job loss experiences. In: Bacharach, S. B. (Ed.), Research in the Sociology of Organizations, 9.

Johnson, J. S., \& Sohi R. S. (2014). The curvilinear and conditional effects of product line breadth on salesperson performance, role stress, and job satisfaction. Journal of the Academy of Marketing Science, 42(1), 71-89. http://dx.doi.org/10.1007/s11747-013-0339-4 
Judge, T. A., \& Church, A. H. (2000). Job satisfaction: Research and practice. In C. L. Cooper \& E. A. Locke (Eds.), Industrial and organizational psychology: Linking theory with practice (166-198). Oxford, UK: Blackwell.

Judge, T.A., \& Watanabe, S. (1993). Another look at the job satisfaction-life satisfaction relationship. J. Appl. Psychol., 6, 939-948. http://dx.doi.org/10.1037/0021-9010.78.6.939

Jurgensen, C. E. (1978). Job preferences (What makes a job good or bad?). Journal of Applie Psychology, 63, 267-276. http://dx.doi.org/10.1037/0021-9010.63.3.267

Katzell, R. A. (1964). Personal values, job satisfaction, and job behavior. In H. Borav, Man in a work at work (341-363) (Chapter 15).

Koustelios, A., Kouli, O., \& Theodorakis, N. (2003). Job security and job satisfaction among Greek fitness instructors. Percept. Mot. Skills., 97(1), 192-4. http://dx.doi.org/10.2466/pms.2003.97.1.192

Kovach, K. A. (1995). Employee motivation: Addressing a crucial factor in your organization's performance. Employment Relations Today, 22, 93-107. http://dx.doi.org/10.1002/ert.3910220209

Lam, T., Baum, T., \& Pine, R. (2001). Study of managerial job satisfaction in Hong Kong's Chinese restaurants. International Journal of Contemporary Hospitality Management, 13(1), 35-42. http://dx.doi.org/10.1108/09596110110365634

Lee-Ross, D. (1998). A practical theory of motivation applied to hotels. International Journal of Contemporary Hospitality Management, 10(2), 68-74. http://dx.doi.org/10.1108/09596119810207219

Locke, E. A. (1976). The nature and consequences of job satisfaction. In M. D. Dunnetter, Handbook of industrial and organizational psychology (1297\} 1349). Chicago: Rand-McNally.

Lyons, K.J., Lapin, J., \& Young, B. (2003). A study of job satisfaction of nursing and allied health graduates from a Mid-Atlantic university. Journal of Allied Health, 32(1), 10-17.

McNeese-Smith, D.K. (1999). A content analysis of staff nurse descriptions of job satisfaction and dissatisfaction. Journal of Advanced Nursing, 29(6), 1332-42. http://dx.doi.org/10.1046/j.1365-2648.1999.01018.x

Moore, W. P., \& Esselman, M. E. (1992). Teacher efficacy, empowerment, and a focused instructional climate:Does student achievement benefit? Paper presented at the annual meeting of the American Educational Research Association, San Francisco.

Moore, W.P., \& Esselman, M. E. (1994). Exploring the context of teacher efficacy: The role of achievement and climate. Annual Meeting of the American Educational Research Association, New Orleans, 4-8 April 1994.

Muijs, R. D., \& Rejnolds, D. (2001). Teachers' beliefs and behaviors: What really matters. Journal of Classroom Interaction, 37, 3-15.

Murray-Gibbons, R., \& Gibbons, C. (2007). Occupational stress in the chef profession. International Journal of Contemporary Hospitality Management, 19(1), 32-42. http://dx.doi.org/10.1108/09596110710724143

Ndubisi, N.O. (2006). Relationship marketing and customer loyalty. Marketing Intelligence \& Planning, 25(1), 98-106. http://dx.doi.org/10.1108/02634500710722425

Nebel, E.C., Braunlich, C.G., \& Zhang, Y. (1994). Career paths in American luxury hotels: hotel food and beverage directors. International Journal of Contemporary Hospitality Management, 6(6), 3-9. http://dx.doi.org/10.1108/09596119410070495

Niels Ole Pors \& Carl Gustav Johannsen. (2002). Job satisfaction and motivational strategies among library directors. New Library World, 103(6), 199-209. http://dx.doi.org/10.1108/03074800210433104

Ning-Kuang Chuang, Dean Yin \& Mary Dellmann-Jenkins. (2008). Intrinsic and extrinsic factors impacting casino hotel chefs' job satisfaction. International Journal of Contemporary Hospitality Management, 21(3), 323-340. http://dx.doi.org/10.1108/09596110910948323

Nunnally, J, C. (1978). Psychometric theory (2nd ed.). New York: McGraw-Hill.

Oldham, G., Julik, C., Ambrose, M., Stepina, L., \& Brand, J. (1986). Relations between job facetcomparisons and employee relations. Organizational Behavior and Human Decision Processes, 38, $28 \pm 47$. http://dx.doi.org/10.1016/0749-5978(86)90024-5

Parisi, A. G., \& Weiner, S. P. (1999, May). Retention of employees: Country-specific analyses in a multinational organization. Poster at the Fourteenth Annual Conference of the Society for Industrial and Organizational 
Psychology, Atlanta, GA.

Patricia Huddleston \& Linda K. Good. (1999). Job motivators in Russian and Polish retail firms. International Journal of Retail \& Distribution Management, 27(9), 383-393. http://dx.doi.org/10.1108/09590559910292843

Pratten, J.D. (2003). The training and retention of chefs. International Journal of Contemporary Hospitality Management, 15(4), 237-42. http://dx.doi.org/10.1108/09596110310475702

Robbins, S. P., \& Coulter, M. (1996). Management. Upper Saddle River, NJ: Prentice-Hall.

Ross, J. A. (1992). Teacher efficacy and the effect of coaching on student achievement. Canadian Journal of Education, 17, 51-65. http://dx.doi.org/10.2307/1495395

Ross, J. A. (1998). The antecedents and consequences of teacher efficacy. In J. Brophy (Ed.), Advances in research on teaching, 7(4974). Greenwich, CT: JAI Press.

Rowley, G., \& Purcell, K. (2001). As cooks go, she went: is labour churn inevitable?. Hospitality Management, 20, 163-85. http://dx.doi.org/10.1016/S0278-4319(00)00050-5

Ryan, R. M., \& E. L. Deci (2000). Intrinsic and extrinsic motivations: Classic definitions and new directions. Contemporary educational psychology, 25(1), 54-67. http://dx.doi.org/10.1006/ceps.1999.1020

Simons, T., \& Enz, C.A. (1995). Motivating hotel employees. Cornell Hotel \& Restaurant Administration Quarterly, $36(1), 20-7$.

Smith, K., Gregory, S.R., \& Cannon, D. (1996). Becoming an employer of choice: assessing commitment in the hospitality workplace. International Journal of Contemporary Hospitality Management, 8(6), 3-9. http://dx.doi.org/10.1108/09596119610129795

Srinivasan, S., \& V. Ambedkar. (2015). Job satisfaction towards teaching profession among the higher secondary school teachers. IJAR, 1(3), 66-68.

Susan J. Linz. (2003). Job satisfaction among Russian workers. International Journal of Man power, $24(6)$, 626-652. http://dx.doi.org/10.1108/01437720310496139

Wang, L. W., \& T. T. Tran (2015). The Study of Teachers' Job Satisfaction in Junior Secondary School Administration System: A Case Study of Vietnamese National Secondary Schools' Teachers. Euro-Asian Journal of Economics and Finance, 3(2), 73-89.

Weiner, S. P. (2000, April). Worldwide technical recruiting in IBM: Research and action. In P. D Bachiochi (Chair), Attracting and keeping top talent in the high-tech industry. Practitioner Forum at the Fifteenth Annual Conference of the Society for Industrial and Organizational Psychology, New Orleans, LA. 